\title{
Gambaran Pengetahuan Akseptor Kb Tentang Penggunaan Kontrasepsi Jangka Panjang Di Wilayah Kerja Puskesmas Pekauman
}

\author{
Laurensia Yunita ${ }^{1}$, Ika Mardiatul Ulfa ${ }^{1}$ \\ ${ }^{1}$ Universitas Sari Mulia \\ *email: laurensia_yunita@akbidsarimulia.ac.id
}

DOI: $\underline{10.33859 / \mathrm{dksm} . v 11 \mathrm{i} 1.610}$

\begin{abstract}
Abstrak
Latar Belakang: Pencapaian akseptor Kb Aktif di Banjarmasin Selatan berjumlah 7.835 orang $(119,4 \%)$ yaitu dari Puskesmas Pekauman 6.498 orang (57,2\%), Puskesmas Kelayan Timur 500 orang (9,8\%), Puskesmas Pemurus Baru 379 orang (7,4\%), Puskesmas Pemurus Dalam 133 orang (4,6\%), Puskesmas Kelayan Dalam 196 (32,7\%), dan Puskesmas Beruntung Raya 129 orang (7,7\%). Dari data tersebut bahwa di Banjarmasin Selatan memiliki 6 Puskesmas dan Puskesmas yang memiliki akseptor Kb Aktif terbanyak adalah Puskesmas Pekauman. Akseptor KB Aktif yang menggunakan Kondom sebanyak 12 orang (0,089\%), suntik sebanyak 819 orang $(6,06 \%)$, dan pil sebanyak 1098 orang $(8,15 \%)$. Kebanyakan Aseptor KB tidak mengetahui apa itu kontasepsi jangka panjang, mereka hanya tau kontrasepsi pil, suntik, impant dan IUD tetapi tidak bisa membedakan mana untuk jangka panjang serta keamannanya bagi akseptor KB.

Tujuan: Mengetahui pengetahuan akseptor KB tentang penggunaan kontrasepsi jangka panjang di wilayah kerja Puskesmas Pekauman.

Metode: Penelitian ini merupakan penelitian diskriftif untuk mengetahui penegtahuan akseptor KB tentang kontrasepsi jangka panjang. Teknik pengambilan sampel adalah Acidental Sampling dengan jumlah sampel sebanyak 30 responden.

Hasil: Dari 30 responden sebanyak 60\% pengetahuan aksepor baik tentang kontrasepsi jangka panjang, sedangkan $40 \%$ pengetahuan aksepor cukup tentang kontrasepsi jangka panjang.

Simpulan: Peranan tenaga kesehatan dalam melakukan penyuluhan tentang alat kontrasesi jangka panjang harus dilakukan dengan maksimal mengingat akseptor kb yang berbeda-beda latarbelakang pengetahuan dan pendidikannya, sehingga capaian pengguna MKJP dapat terpenuhi.
\end{abstract}

Kata Kunci: Akseptor, Kontrasepsi, KB, Pengetahuan 


\section{Abstract}

Background: Achievement of active Kb acceptors in South Banjarmasin amounted to 7,835 people (119.4\%), namely from the Pekauman Health Center 6,498 people (57.2\%), the East Kelayan Health Center 500 people (9.8\%), the Health Center Pemurus Baru 379 people ( 7.4\%), Health Center Pemurus Dalam 133 people (4.6\%), Health Center Kelayan Dalam 196 (32.7\%), and Health Center Beruntung Raya 129 people (7.7\%). Health center Pekauman acceptors of active birth control using condoms were 12 people (0.089\%), injected 819 people (6.06\%), and 1098 people $(8.15 \%)$ pills. Most contraception acceptors do not know what long-term contraception is, they only know the contraceptive pill, injection, impant and IUD but cannot distinguish which for the long term and its safety for family planning acceptors.

Objective: Knowing the knowledge of family planning acceptors about contraceptive use in the work area of the Health center Pekauman.

Method: This research is a descriptive study to study the knowledge of family planning acceptors about long-term contraception. The sampling technique is accidental sampling with a total sample of 30 respondents.

Results: Of the 30 respondents, $60 \%$ of acceptor knowledge is good about long-term contraception, while $40 \%$ of acceptor knowledge is enough about long-term contraception.

Conclusion: The role of health workers in conducting counseling about long-term contraction tools must be carried out with a maximum of acceptors who have different background knowledge and education, so that the achievements of MKJP users can be fulfilled.

Keywords: Acceptor, Contraception, KB, Knowledge

\section{PENDAHULUAN}

Di Indonesia masalah utama yang di hadapi yaitu masalah tentang peningkatan jumlah penduduk yang tinggi setiap tahunnya. Statistik menunjukkan jumlah kependudukan Indonesia pada tahun 2010-2015 mengalami peningkatan yang sangat drastis. Proyeksi kependudukan di Kalimantan Selatan terus meningkat dari tahun ketahun di mulai dari tahun 2010-2015 yaitu $2010: 3.642,6$ juta jiwa, $2011:$ 3,714,3 juta jiwa, 2012 : 3.785,0 juta jiwa, 2013 : 3,854,5 juta jiwa, 2014 : $3.922,8$ juta jiwa, $2015: 3.989,8$ juta jiwa (Statistik, 2015)

KB merupakan program dari pemerintah untuk menjarangkan atau merencanakan jumlah anak dan jarak kehamilan dengan menggunakan kontrasepsi (Ari Sulistyawati, 2011). Dalam program KB, terdapat berbagai jenis Metode Kontrasepsi Jangka Panjang (MKJP) diantaranya Alat Kontrasepsi Dalam Rahim (AKDR), Alat Kontrasepsi Bawah 
Dinamika Kesehatan Jurnal Kebidanan dan Keperawatan Vol 11 No. 1 Juli 2020 ( ISSN: 2086-3454 EISSN: 2549-4058)

url: http://ojs.dinamikakesehatan.unism.ac.id DOI : https://doi.org/10.33859/dksm.v11i1

Gambaran Pengetahuan Akseptor Kb Tentang Penggunaan Kontrasepsi Jangka Panjang Di Wilayah Kerja Puskesmas Pekauman

Kulit (AKBK) dan Kontrasepsi Mantap seperti

Vasektomi (MOP) dan Tubektomi (MOW).

(Afnita, 2015)

MKJP merupakan kontrasepsi yang dapat digunakan dalam jangka lama, lebih dari dua tahun efektif dan efisien untuk tujuan pemakaian menjarangkan kelahiran lebih dari tiga tahun atau sudah tidak ingin tambah anak lagi (Prawirohardjo,2009). Menurut Nasution (2011) pengguna MKJP kebanyakan merupakan wanita dengan pendidikan SLTA. Faktor pengetahuan merupakan faktor dominan dalam pengambilan keputusan untuk pemilihan alat kontrasepsi yang digunakan. Kategori MKJP adalah jenis susuk/implant, IUD, MOP (Metode Operasi Pria), dan MOW (Metode Operasi Wanita). Sedangkan yang termasuk dalam kategori Non-MKJP adalah suntik, pil dan kondom (DEPKES, 2008).

\section{Menurut World Health Organization}

(WHO) bahwa lebih dari 100 juta wanita di dunia menggunakan kontrasepsi yang memiliki efektifitas dengan persentase $75 \%$ kontrasepsi hormonal dan 25\% non hormonal. Di Afrika tercatat sebanyak $82 \%$ penduduknya tidak menggunakan kontrasepsi. Di Asia Tenggara, Selatan, dan Barat pengguna kontrasepsi sebanyak 43\% (Nirwana, 2012). Pengguna kontrasepsi di dunia pada tahun 2005 mencapai 89\%. Tahun 2007 angka pengguna $\mathrm{KB}$ modern di perkotaan mencapai 58\% sedangkan di pedesaan mencapai 57\% (Kemenkes RI, 2014).

Data dari dinas kesehatan kota Banjarmasin tentang pencapaian akseptor $\mathrm{Kb}$ Aktif di Banjarmasin Selatan dari tahun 2015 berjumlah 7.835 orang $(119,4 \%)$ yaitu dari Puskesmas Pekauman 6.498 orang $(57,2 \%)$, Puskesmas Kelayan Timur 500 orang (9,8\%), Puskesmas Pemurus Baru 379 orang (7,4\%), Puskesmas Pemurus Dalam 133 orang (4,6\%), Puskesmas Kelayan Dalam 196 (32,7\%), dan Puskesmas Beruntung Raya 129 orang (7,7\%). Dari data tersebut bahwa di Banjarmasin Selatan memiliki 6 Puskesmas dan Puskesmas yang memiliki akseptor $\mathrm{Kb}$ Aktif terbanyak adalah Puskesmas Pekauman (Dinkes, 2016).

Dari hasil data di Puskesmas Pekauman Banjarmasin Selatan tahun 2013 akseptor KB Aktif yang menggunakan IUD berjumlah 50 
Dinamika Kesehatan Jurnal Kebidanan dan Keperawatan Vol 11 No. 1 Juli 2020 ( ISSN: 2086-3454 EISSN: 2549-4058)

url: http://ojs.dinamikakesehatan.unism.ac.id DOI : https://doi.org/10.33859/dksm.v11i1

Gambaran Pengetahuan Akseptor Kb Tentang Penggunaan Kontrasepsi Jangka Panjang Di Wilayah Kerja Puskesmas Pekauman

orang $(0,338 \%)$, implant sebanyak 79 orang (0,534\%). Tahun 2014 akseptop KB Aktif yang menggunakan IUD berjumlah 38 orang $(0,296 \%)$, implant sebanyak 72 orang (0,561\%). Tahun 2015 akseptop KB Aktif yang menggunakan IUD berjumlah 23 orang $(0,181 \%)$, implant sebanyak 55 orang (0,435\%). Dan tahun 2015 Akseptor KB Aktif yang menggunakan Kondom sebanyak 12 orang $(0,089 \%)$, suntik sebanyak 819 orang (6,06\%), dan pil sebanyak 1098 orang $(8,15 \%)$.

Pada saat study pendahuluan kebanyakan Aseptor KB tidak mengetahui apa itu kontasepsi jangka panjang, mereka hanya tau kontrasepsi pil, suntik, impant dan IUD tetapi tidak bisa membedakan mana untuk jangka panjang serta keamannanya bagi akseptor KB.

\section{BAHAN DAN METODE}

Penelitian ini dilakukan di Puskesmas Pekauman Banjarmasin. Metode penelitian yang digunakan dalam penelitian ini adalah deskriptif. Sampel dalam penelitian ini berjumlah 30 orang. Teknik Pengambilan sampel yaitu Acidental Sampling.

Data yang dikumpulkan dan diperoleh secara manual serta disajikan dalam bentuk distribusi frekuensi, kemudian dianalisa secara diskriftif untuk mengetahui penegtahuan akseptor KB tentang kontrasepsi jangka panjang.

\section{HASIL PENELITIAN}

1. Analisis Univariat

Tabel 1 Pengetahuan berdasarkan Karakterisitik Responden

\begin{tabular}{ccc}
\hline Karakteristik & Baik & Cukup \\
\hline Umur & & \\
$20-35^{\text {th }}$ & 10 & 8 \\
$>35$ th & 8 & 4
\end{tabular}

Pendidikan terakhir

$\begin{array}{cll}\text { SD } & 1 & 5 \\ \text { SMP } & 4 & 3 \\ \text { SMA } & 9 & 1 \\ \text { PT } & 1 & 0\end{array}$

Pekerjaan

$\begin{array}{ccc}\text { IRT } & 9 & 10 \\ \text { Swasta } & 2 & 2 \\ \text { PNS } & 7 & 0 \\ \text { Honnor } & 0 & 0\end{array}$

Kontrasepsi

$\begin{array}{lll}\text { Pil } & 10 & 10\end{array}$

Suntik

$8 \quad 2$

Berdasarkan tabel 1 diperoleh hasil bahwa sebagian besar responden 
berumur 20-35 tahun sebanyak 18 orang dengan pengetahuan baik sebanyak 10 orang, sedangkan 8 orang berpengetahuan cukup. Dilihat dari pendidikan terakhir yakni SMA sebanyak 9 orang dengan pengetahuan baik dan 1 orang yang berpengetahuan cukup. Dilihat dari pekerjaan, sebagian besar responden dengan pekerjaan IRT yaitu sebanyak 9 orang berpengetahuan baik, sedangkan 10 orang berpengatahuan cukup. Dilihat dari pengguna kontrasepsi sebelumnya, sebanyak 10 orang menggunakan pil dan berpengetahuan baik, sedangkan, 10 orang pengguna pil berpengetahuan cukup.

Tabel 2. Distribusi responden berdasarkan pengetahuan akseptor tentang kontrasepsi jangka panjang di Puskesmas Pekauman Banjarmasin

\begin{tabular}{ccc}
\hline Pengetahuan & $\mathrm{n}$ & Persentasi (\%) \\
\hline Baik & 18 & 60 \\
Cukup & 12 & 40 \\
\hline Jumlah & 30 & 100 \\
\hline
\end{tabular}

\section{PEMBAHASAN}

Hasil penelitian ini didukung oleh hasil penelitian Sri Maryani 2013 yang menunjukkan bahwa pemilihan alat kontrasepsi dipengaruhi oleh berbagai faktor seperti karakteristik demografi umur, status pendidikan, jumlah anak, status kesehatan, pengetahuan dan dukungan suami. Berdasarkan hasil analisis data dari pernyataan yang ada didalam kuesioner bahwa banyak responden yang berumur 20 35 tahun yang mendukung pemilihan kontrasepsi jangka panjang, karena diumur itu usia ibu sangat reproduktif. Dan diantara usia itu adalah fase menjarangkan kehamilan bagi PUS . Wanita mengalami kehamilan dan kelahiran terbaik, yaitu yang berisiko paling rendah untuk ibu dan anak adalah antara 2035 tahun. Menurut Nasution (2011) dan Asih (2009) menyatakan bahwa pemakai MKJP sebagian besar digunakan oleh wanita yang berusia $>30$ tahun.

Berdasarkan hasil analisis data dari pernyataan yang ada didalam kuesioner bahwa banyak responden yang bekerja 
Dinamika Kesehatan Jurnal Kebidanan dan Keperawatan Vol 11 No. 1 Juli 2020 ( ISSN: 2086-3454 EISSN: 2549-4058)

url: http://ojs.dinamikakesehatan.unism.ac.id DOI : https://doi.org/10.33859/dksm.v11i1

Gambaran Pengetahuan Akseptor Kb Tentang Penggunaan Kontrasepsi Jangka Panjang Di Wilayah Kerja Puskesmas

sebagai ibu rumah tangga yang banyak didukung pemilihan kontrasepsi jangka panjang, dimana mungkin dari segi pekerjaan ibu rumah tangga ingin menggunakan kontrasepsi jangka panjang melihat dari pekerjaan nya hanya banyak dirumah, tidak bekerja berat dan tidak menganggu penggunaan kontrasepsi itu. Dan berdasarkan hasil analisis data dari pernyataan yang ada didalam kuesioner bahwa banyak responden yang berpendidikan SD yang banyak didukung pemilihan kontrasepsi jangka panjang, dimana mungkin darisegi pendidikan itu ibu mendapatkan informasi dan lingkungan sekitar dan tetangga dan ibu bisa mendapatkan informasi tentang kontrasepsi jangka panjang di media, keluarga ataupun kawan.

Dari penelitian ini banyaknya yang menggunakan selain kontrasepsi jangka panjang yang permanen seperti suntik dan pil itu karena dari segi biaya suntik dan pil bagi akseptor lebih murah dibandingkan kontrasepsi yang jangka panjang, dan kurang nya pengetahuan dari masyarakat tentang kontrasepsi jangka panjang sehingga banyak yang tidak berminat menggunakan kontrasepsi jangka panjang.

Menurut Nasution (2011) bahwa usia $>35$ tahun merupakan usia yang rawan dan berisiko untuk hamil sehingga dengan menggunakan MKJP lebih aman dan lebih efektif mencegah kehamilan. Bagi ibu yang berusia kurang dari 35 tahun dan memiliki anak lebih dari 2 sebaiknya menggunakan alat kontrasepsi MKJP, hal ini menghindari drop out yang tidak diinginkan, mengingat ibu termasuk usia muda dan kurun waktu bereproduksi masih cukup panjang. Dari penelitian ini hanya 2 responden yang usia $>35$ tahun yang mendukung dalam pemilihan kontrasepsi jangka panjang karena hanya terdapat 2 responden yang usia $>35$ tahun.

Pengetahuan responden tentang $\mathrm{KB}$ MKJP merupakan pemahaman responden tentang pengertian $\mathrm{KB}$ MKJP, macam KB MKJP, fungsi dan manfaat KB MKJP, penggunaan KB MKJP dan efek samping KB MKJP. Hasil Penelitian mengenai tingkat pengetahuan responden tentang KB MKJP di 
Dinamika Kesehatan Jurnal Kebidanan dan Keperawatan Vol 11 No. 1 Juli 2020 ( ISSN: 2086-3454 EISSN: 2549-4058)

url: http://ojs.dinamikakesehatan.unism.ac.id DOI : https://doi.org/10.33859/dksm.v11i1

Gambaran Pengetahuan Akseptor Kb Tentang Penggunaan Kontrasepsi Jangka Panjang Di Wilayah Kerja Puskesmas Pekauman

wilayah kerja Puskesmas Pekauman

menunjukkan sebagian besar responden

memiliki pengetahuan yang cukup, yaitu sebanyak 12 responden (40\%), salah satu dari penyebab pengetahuan cukup tersebut adalah dalam kuesioner pengetahuan terdapat beberapa pertanyaan mengenai $\mathrm{KB}$ secara umum dan spesifik KB MJKP, dimana pengetahuan tersebut mudah dipahami meskipun secara umum pengetahuan itu cukup. Tingkat pengetahuan tentang KB MKJP tersebut dipengaruhi oleh adanya beberapa faktor pendukung pengetahuan yang ada disekitar responden antara lain pendidikan, pekerjaan dan umur (Wawan dan Dewi, 2010). Sementara itu Mubarrak menyatakan bahwa secara umum pengetahuan seseorang dipengaruhi oleh pendidikan, pekerjaan, usia, minat, pengalaman hidup, budaya dan informasi. Pendidikan juga berperan penting dalam pembentukan kecerdasan manusia maupun perubahan tingkah lakunya. Pendidikan juga berarti bimbingan yang diberikan seseorang kepada orang lain terhadap sesuatu hal agar mereka dapat memahami. Tidak dapat dipungkiri bahwa semakin tinggi pendidikan seseorang maka semakin mudah pula mereka menerima informasi. Pada akhirnya banyak pula pengetahuan yang dimilikinya. Sebaliknya jika seseorang memiliki tingkat pendidikan yang rendah maka akan menghambat perkembangan sikap seseorang terhadap penerimaan informasi. (Mubarakdkk, 2009)

Berdasarkan tingkat pendidikan responden, menunjukkan bahwa sebagian besar responden memiliki pendidikan yang baik yaitu SLTA, dimana tingkat pendidikan dalam Undang-undang No. 23 tahun 2003 tentang Sistem Pendidikan Nasional, dinyatakan bahwa tingkat pendidikan menengah yaitu 9 tahun merupakan batas minimil tingkat pendidikan yang baik. Hal tersebut sebagaimana dikemukakan oleh Kusumaningrum yang menyatakan bahwa tingkat pendidikan yang dimilikimempunyai pengaruh kuat pada perilaku reproduksi dan penggunaan alat konterasepsi. Tingkat pendidikan responden tersebut tergolong 
Dinamika Kesehatan Jurnal Kebidanan dan Keperawatan Vol 11 No. 1 Juli 2020 ( ISSN: 2086-3454 EISSN: 2549-4058)

url: http://ojs.dinamikakesehatan.unism.ac.id DOI : https://doi.org/10.33859/dksm.v11i1

Gambaran Pengetahuan Akseptor Kb Tentang Penggunaan Kontrasepsi Jangka Panjang Di Wilayah Kerja Puskesmas Pekauman

baik yang mampu menopang kemampua

mereka untuk menangkap dan memahami

informasi-informasi dari luar yang

merupakan sumber pengetahuan tentang $\mathrm{KB}$

MKJP. Informasi-informasi tersebut

diperoleh dari teman, petugas kesehatan,

orang tua, media informasi, internet dan lain-

lain.

\section{KESIMPULAN}

A. Simpulan

Berdasarkan hasil penelitian dan pembahasan yang telah disampaikan pada bab sebelumnya, maka simpulan yang dapat diambil dari penelitian ini adalah Sebagian besar responden memiliki pengetahuan baik sebesar $60 \%$ tentang Kontrasepsi jangka panjang.

Karekteristik responden didominasi oleh usia ibu 20-35 tahun dengan jumlah 18 orang, jenjang pendidikan paling banyak berpendidikan SMA yaitu berjumlah 10 orang, dan pekerjaan Ibu Rumah
Tangga paling banyak yaitu berjumlah 19 orang.

B. Saran

Berdasarkan hasil penelitian yang sudah dilakukan, maka beberapa saran dalam penelitian ini adalah:

1. Menambah jumlah data yang lebih besar dan atribut yang lebih banyak sehiingga hasil pengukuran akan di dapat lebih baik lagi.

2. Menggunakan metode penelitian yang berbeda serta teknik sampling yang berbeda

3. Meningkatkan lagi sistem analisa pengguna kontrasepsi jangka panjang di daerah-daerah yang memiliki tingkat yang rendah dalam penggunaan kontrasepsi tersebut. 


\section{DAFTAR PUSTAKA}

Atika Proverawati, 2010. Panduan memilih kontrasepsi. Yogyakarta: Nuha Medika.

Arikunto, 2010. Prosedur Penelitian Suatu Pendekatan Praktik. Jakarta: PT Rineka Cipta.

Aziz Alimul Hidayat.2007.Metode Penelitian Keperawatan dan Teknik Analisa Data.Jakarta: Salemba Medika.

Aziz Alimul Hidayat.2011.Metode Penelitian Keperawatan dan Teknik Analisa Data.Jakarta: Salemba Medika.

BKKBN.2015.Bandung.BKKBN gandeng IBI dan IDI demi mencapai target MDGs 2015 [Internet].Tersedia dalam: http://www.jdih.net/web bppkb/berita/2 69/bkkbn-gandeng-ibi-dan-idi-demicapai-target-mdgs-2015.

Dagun SM, 2009. Psikologi Keluarga Peran Ayah dalam Keluarga. Jakarta: Rineka Cipta.

Dinas Kesehatan Kota Banjarmasin. 2013. Cakupan Pelayanan KB Banjarmasin.

Farida, Umi. 2008. Dukungan Suami dengan Pemilihan Metode Kontrasepsi. STIKES Aisyiyah Jogjakarta.

Hartanto, Hanafi.2005. Keluarga Berencana dan Kontrasepsi. Jakarta: Pustaka Sinar Harapan.

Handayani, S. 2010. Keluarga Berencana dan Kontrasepsi. Yogyakarta: Pustaka Rihana.

Kementerian Kesehatan RI. 2013. Riset Kesehatan Dasar, Riskesdas 2013. Kementerian Kesehatan RI, Jakarta.

Kementerian Kesehatan RI. 2013. Rencana aksi nasional pelayanan keluarga berencana tahun 2014-2015. Jakarta .
Kementerian Kesehatan RI. 2014. Profil Kesehatan Indonesia Tahun 2013. Kementerian Kesehatan RI, Jakarta.

Manaf S 2010. Pengaruh terhadap dukungan suami dan pembuatan keputusan terhadap pemilihan kontrasepsi.

Mulyani, Nina Siti.2013. Keluarga Berencana dan Alat Kontrasepsi. Yogyakarta: Nuha Medika.

Notoadmodjo Soekitdjo.2010.Metodologi Penelitian Kesehatan, Jakarta: Rineka Cipta.

Pedoman Pelayanan Keluarga Berencana Pasca Persalinan di Fasilitas Kesehatan (BKKBN dan Kemenkes R.I., 2012).

Prasetyawati, A.E. 2011. Ilmu Kesehatan Masyarakat. Yogyakarta. Nuha Medika.

Puskesmas Pekauman.2015. Pencatatan dan Pelaporan KB Puskesmas Pekauman. Kalimantan Sekatan: Puskesmas Pekauman.

Saifudin BA, dkk.2006. Buku Panduan Praktis Pelayanan Kontrasepsi, Yayasan Bina Pustaka, Jakarta

Sarwono Prawirohardjo, 2010.. Ilmu Kebidanan. Jakarta: Yayasan Bina Pustaka . 